\title{
The Relationship between Extent of Internationalization and Firm Performance (Taiwan 1992-2017)
}

\author{
Shih-Yung Wei ${ }^{1}$ and Li-Wei Lin (iD) ${ }^{2}$ \\ ${ }^{1}$ Business School of Yulin Normal University, Yulin, China \\ ${ }^{2}$ The School of International Business, Zhejiang Yuexiu University, No. 428 Kuaiji Road, Yue Cheng District, \\ Shaoxing 312000, China \\ Correspondence should be addressed to Li-Wei Lin; linlw1982@gmail.com
}

Received 30 January 2021; Revised 10 May 2021; Accepted 24 May 2021; Published 12 June 2021

Academic Editor: Maria Angela Butturi

Copyright (c) 2021 Shih-Yung Wei and Li-Wei Lin. This is an open access article distributed under the Creative Commons Attribution License, which permits unrestricted use, distribution, and reproduction in any medium, provided the original work is properly cited.

\begin{abstract}
The purpose of this study was to discuss the impact of the extent of internationalization on firm performance measured for firms with a high Tobin's Q (firms with good operating performance), a median Tobin's Q (firms with average operating performance), and a low Tobin's Q (firms with poor operating performance). In addition to discussion on the impact of internationalization on firm performance, this study also discussed the impact of corporate proprietary assets (using assets, R\&D, marketing, and management-related variables as moderating variables) and control variables (scale of company, debt-asset ratio, firm age, board structure, and proportion of pledged shares by directors) on firm performance. The research results showed that there is an S-shaped relationship between extent of internationalization and firm performance. However, further discussion found that there is an S-shaped relationship between extent of internationalization and performance for firms with a high Tobin's Q but a slight decline in the middle of the S-shaped curve, as well as a general linear negative correlation between extent of internationalization and performance for firms with a median Tobin's Q and an inverted U-shaped correlation between extent of internationalization and performance for firms with a low Tobin's Q.
\end{abstract}

\section{Introduction}

Taiwan's per capita GDP surpassed US\$10,000 in 1992 to become a developed economy. In 1993, Taiwan was rated as one of the top 20 economies in the world. Therefore, this study selected data having been acquired since the 21st century. Taiwan's economic development results have always been a model for the world, but there is currently little literature discussing the impact of Taiwan's internationalization and corporate performance. Therefore, this article explores whether the degree of Taiwan's internationalization has the same impact on company performance as scholars in the past. Scholars used to have different views on the concept of internationalization, and the definitions of the variables were also different. Michael Geringer et al. [1] advocated the degree of internationalization, Dess et al. [2] used the degree of international polygonization, Delios and Beamish [3] and Dess et al. [2] took the term of regional polygonization, and
Grant [4] and Kotabe et al. [5] coined the term "multinationalization." Apart from terminological differences, opinions also varied on variable measurement. Some methods measured a single item, while others created a single pointer with multiple items for measurement. In fact, each method of measurement reflects the value of different degrees of overseas involvement [6], and appropriate indicators should be used to measure the international polygonization of different countries [7].

There are five operational ways to measure the degree of corporate internationalization by performance attributes. They are, respectively, the proportion of overseas sales to total sales (FSTS), research development intensity (RDI), advertising intensity (AI), proportion of export sales to total sales (ESTS), and proportion of foreign profits to total profits (FPTP). Kafouros et al. [8], Bae et al. [9], and Filatotchev and Piesse [10] used FSTS to measure corporate internationalization. Caves [11] believed that R\&D activities can predict 
the growth of multinational enterprises. Franko [12] also found that research and development intensity (RDI) is an important principle to gain market share under global competition. Similarly, some held that the scale of marketing functions of multinational enterprises is another important principle. Caves [11] believed that using advertising intensity (AI) for measurement contributes to explaining the degree of corporate internationalization. Sullivan [13] pointed out that ESTS, indicating the intensity of export activities, can differentiate the degree of corporate internationalization. Eppink and Van Rhijn [14] called for the use of the proportion of foreign profits to total profits (FPTP) to measure the degree of internationalization.

In the early stage of internationalization, due to an investment environment different from that in Taiwan, unfamiliar laws and regulations, and massive initial investments of fixed costs, firms generally failed to obtain profits from overseas markets to maintain their operation. Firms should neither cut investment in internationalization nor cease their efforts in internationalization due to performance decline and instead should focus on how to improve various adverse factors and address the performance decline in the early stage of internationalization as a result of the increase in learning costs and deficiencies in economies of scale. For example, the performance decline as a result of the increase in learning costs and deficiencies in economies of scale in the early stage of internationalization can be mitigated through increasing investments in corporate proprietary assets (such as R\&D strength), thereby minimizing the duration and extent of the performance decline and progressively highlighting the function of internationalization while improving performance. In addition, management has to review the national environment in the early stage of international expansion, so as to minimize potential adverse factors. One method, based on the threshold effect, is to develop the capability to manage complexity [15] or overcome dilemmas in corporate management through controlling time and management and finally to reduce the possibility of business failure as a result of insufficient profit during this stage.

In stage 2 of international expansion, with the increased extent of corporate internationalization, firm performance bounces back from the bottom and turns from negative to positive. Firms should strive to extend this stage as far as possible so as to extend the duration and increase the extent of performance improvements, and they should act prudently to avoid issues in management coordination due to an excessively large organizational structure as a result of extreme expansion. The extent of internationalization is expected to continue to improve in this stage, while performance decline is expected in the next stage. Therefore, it is greatly important to know how to maintain the duration and increase the extent of the performance-improving stage and postpone the time point of the decline of performance as a result of improving the extent of internationalization. A feasible solution is to develop and utilize corporate proprietary assets, such as R\&D and capital strength, that can assist in realizing economies of scale and scope and extend the lifetime of products, so as to extend the duration and increase the extent of performance improvement and postpone the time point of the decline of performance in the future.

In the last stage, i.e., stage 3, with the increasing extent of internationalization, performance decline can be observed upon reaching maximum performance. Not all firms will be subject to stage 3; however, all firms should strive to mitigate the risk of performance decline due to the increase of coordination costs as a result of excessive internationalization upon entering this stage. Moreover, firms should learn and accumulate experiences in the international environment and improve their management capabilities so as to make a breakthrough and enter a new profit-making stage. As global operations are quite complicated under an extensive international expansion, coordination and management costs will exceed the profits generated from expansion. However, profits will rise if management learns to properly manage such new complexity, which can be achieved constantly through learning [16]. In such a case, firms can further mitigate the aforementioned performance decline as a result of excessive internationalization through increasing investments in proprietary corporate assets.

The results of this research demonstrated the three-stage theory proposed by scholars $[17,18]$. In the early stage of internationalization, firms have to invest substantial costs in areas such as employees, equipment acquisition, and the establishment of internal management systems and external corporate networks. In addition, due to the increase in learning costs and deficiencies in economies of scale in the early stage, a negative correlation between internationalization and performance is observed and a performance decline is recorded. In stage 2 , however, with the increasing extent of internationalization, the accumulation of knowledge and experience regarding international operations, and the benefits of internationalization, a positive correlation between internationalization and performance is observed and performance improvement is recorded due to the increase and development of corporate resources, the internalization of transaction costs, the realization of economies of scale and scope, the extended lifetime of products, the acquisition of low-cost resources, and other factors. In stage 3 , however, a negative correlation between internationalization and performance is observed again due to the coordination costs incurred by cultural distance and fragmented markets; that is to say, performance starts to decline again when internationalization reaches a certain extent. The continuous increase in the extent of internationalization leads to a more complicated international operation as well as increased management and coordination costs, and hence, the diminishing performance. In view of the above, internationalization involving direct overseas investment should be conducted to an appropriate extent; otherwise, both excessive and insufficient internationalization will lead to poor performance.

The concept of internationalization was first developed by Errunza and Senbet [19] using 60 items of excess compensation as a research source and found that companies with a high degree of internationalization have better market evaluations. However, scholars have never had a common 
view on the concept of internationalization, and foreign literature has more abundant research on internationalization. The abovementioned influence results are all related to scholars' research. This topic focuses on foreign scholars' research on my country's situation. In summary, Filatotchev and Piesse [10] studied the experience of MNCs of 711 SMEs entrepreneurs and found that the market share sales growth pretax gross profit is negatively correlated; but the interaction effect between the two is positively correlated. Recently, Chen et al. [20] considered a sample of 118 listed companies from 2006 to 2011 and found that private and specific regional marketization helps companies obtain international performance gains, while public operation plays a negligible role. The role of Zhou [21] studied 535 manufacturing companies of A-share listed companies from 2001 to 2014. The overall sample's international performance relationship is $\mathrm{W}$-shaped, but changes with the size of the company. Specifically, small companies are $\mathrm{W}$-shaped and large companies are U-shaped. Kim et al. [22] studied 767 publicly listed companies from 2002 to 2014 and found that the faster the regional internationalization, the better the company's financial status, and the faster the regional internationalization, the worse the financial status.

Overall, the research on the impact of internationalization on company performance has different results, irrelevant [23-25], linear $[19,20,26,27]$, $U$ shape $[6,18,21,28,29], S$ type [17], and higher power $\mathrm{W}$ type [21], and different external factors will have different effects.

As for the research on international performance, most scholars in the past adopted cross-sectional analysis (without considering time series), and there were very few studies on solving endogenous problems. The first task of empirical research is the rigor of research. The most important thing is to solve the endogenous and exogenous problems of the research process. Therefore, this article uses panel data analysis suitable for big data analysis to conduct research. In addition, in different environments, internationalization, many scholars have analyzed the impact of company' performance, but there are few that use different companies' performance to distinguish. The second analysis of this article focuses on analyzing how internationalization affects performance under different companies' performance, impact.

The structure of this article is divided into 4 sections. The first section is Introduction, which introduces the research purpose and motivation of this article and related literature.
The second section is the Research Data and Research Method, which mainly introduces the research data and related variables of this article and also the calculation of and the research methods used in this study. The third section is empirical analysis. The empirical results are carried out through relevant data and research methods. The last one is the Conclusions and recommendations of this research.

\section{Research Data and Research Method}

2.1. Research Data. The total number of samples of this study, after deleting those of incomplete data, is 27062 from 2175 listed companies (excluding the financial sector) in Taiwan from 1992 to 2017 (source: TEJ; Taiwan Economic Journal).

2.2. Research Variable. There are three main variables in empirical analysis: independent variable, dependent variable, and control variable. In this study, the independent variable is the degree of corporate internationalization; the dependent variable is corporate performance; apart from the dependent variable, the control variable covers all variables that exert an impact on corporate performance. This study adopts $8+3$ variables, including the proportion of shares pledged by directors (Pledge), debt-asset ratio (DA), scale of company, structure of board of directors (3 types), R\&D expense ratio, firm age, and growth rate of fixed assets (Lasset). The variables of this study are introduced in detail as follows.

\subsubsection{Independent Variable: Degree of Internationalization.} There are many indicators related to the degree of internationalization. This study uses the sales area to measure, namely, by the proportion of overseas sales to total sales (FSTS).

2.2.2. Corporate Performance (Tobin's Q). This study adopts Tobin's Q, the most commonly used indicator to measure a company's market performance. La Porta et al. [30] employed Tobin's Q, but failed to figure out Tobin's Q because they could not obtain the replacement cost of company' assets. As a result, they replaced Tobin's Q with Proxy Q, and the latter was adopted by Claessens et al. [31]. Proxy Q is measured as follows:

$$
\begin{aligned}
\text { Tobin's } Q & =\frac{\text { Market value of equity }+ \text { market value of debts }}{\text { Asset replacement cost }} \\
\text { Proxy } Q & =\frac{\text { Market value of equity }(\text { common stocks }+ \text { special stocks })+\text { book value of debts }}{\text { Book value of assets }} .
\end{aligned}
$$

2.2.3. Moderating Variable: Measurement of Corporate Proprietary Assets. When firms obtain differential benefits from international expansion, they should maximize the benefits of internationalization and minimize the costs of internationalization with their capabilities. Such capabilities could be considered proprietary corporate assets. 
Proprietary corporate assets include a firm's R\&D and its capital strength [32]. Therefore, this study believed that a firm's $R \& D$ and capital strength could enable the firm to obtain benefits from an internationalization strategy.
(1) Growth Rate of Fixed Assets (LA). Agrawal and Knoeber [33] and Wei et al. [34] noted that the higher the growth rate of fixed assets is, the more opportunities for future investment and growth a company has. The growth rate of fixed assets is also an indicator of corporate performance

$$
\mathrm{LA}=\frac{\text { (Total fixed assets of the year }- \text { total fixed assets of the previous year) }}{\text { Total fixed assets of the previous year }} \text {. }
$$

(2) R\&D Expense Ratio to Total Sales (RD). Bradley et al. [35], Morck et al. [36], and Wei et al. [34] agreed that the more the corporate $\mathrm{R} \& \mathrm{D}$ expenses are, the better is the potential for company growth.

$$
\mathrm{R} \& \mathrm{D} \text { expense ratio }=\frac{\mathrm{R} \& \mathrm{D} \text { expense }}{\text { Sale revenues }} .
$$

(3) Strength in Marketing. Morck and Yeung [37] found that under international M\&As of major firms, investors have a positive impact on the market value of firms. Kravis and Lipsey [38] demonstrated that both firms' R\&D investment and advertisement costs could contribute to improving export performance. Kotabe et al. [5] and Lu and Beamish [18] demonstrated that higher advertisement and marketing costs could contribute to improving the sales of international firms in overseas markets. Shah et al. [39] utilized crosssectional data from 1990 to 1998 in the UK and 9,752 observed values to research the value relevance of the main media advertisement costs of ACNielsen MEA, and the results showed a positive correlation between advertisement costs and the market value of the firm. The marketing expense ratio refers to the marketing cost of a firm (including costs for publishing advertisements in newspapers and magazines, on television stations, at cinemas and theaters, advertisement designs and productions from advertising agencies, touring propaganda, color advertising boards, electric advertising, and printing of advertising materials, as well as free samples and items) within a certain period (generally one year) divided by operating revenue. This ratio is generally expressed as a percentage:

$$
\text { Strength in marketing }(\mathrm{MI})=\frac{\text { Marketing cost }}{\text { Sale revenues }} \text {. }
$$

(4) Management Expense Ratio. The management expense ratio refers to the management cost of a firm (including salaries, employee benefits, depreciation costs, office costs, travel costs, transportation costs, insurance costs, rental costs, repair costs, consultancy costs, legal costs, and sewage charges) within a certain period (generally one year) divided by operating revenue. This ratio is generally expressed as a percentage:

$$
\text { Strength in marketing }(\mathrm{MI})=\frac{\text { Management cost }}{\text { Sale revenues }} .
$$

\subsubsection{Control Variables}

(1) Scale of Company (SC). Firms with a large scale can generally be regarded as having the capability to acquire a profit margin above the normal level, as compared with general firms. Therefore, such firms are able to operate in an imperfect market and acquire a higher excess profit by leveraging their monopoly or oligopoly strength. Furthermore, firms with a large scale may have access to funds with low cost in the capital market or operate in the market with low cost due to risk diversification.

In respect of the impact of the scale of a company on performance, it is easier for firms with a larger scale to utilize the advantage of economies of scale to result in good operating performance. Therefore, scale of company was defined as a control variable. Measurement of the scale of company includes total assets, total operating revenue, and number of employees [5, 9, 18, 23, 40]. Generally, the total assets or operating cost of a firm at natural logarithms is defined as a proxy variable. Therefore, in this study, the carrying amounts of the total assets of the sample firms at natural logarithms were used as proxy variables.

$$
\text { Scale of company }=\log \text { (total assets). }
$$

(2) Debt-Asset Ratio (DA). Myers and Turnbull [41], Stulz [42], and Wei et al. [34] argued that the debt-asset ratio, on the one hand, implies the information of corporate tax shields; on the other hand, according to the pecking order theory, the higher the debt-asset ratio is, the lower the rate on investment is and the smaller the corporate value will be.

$$
\text { Debt }- \text { asset ratio }=\frac{\text { Book value of debt }}{\text { Book value of asset }} .
$$




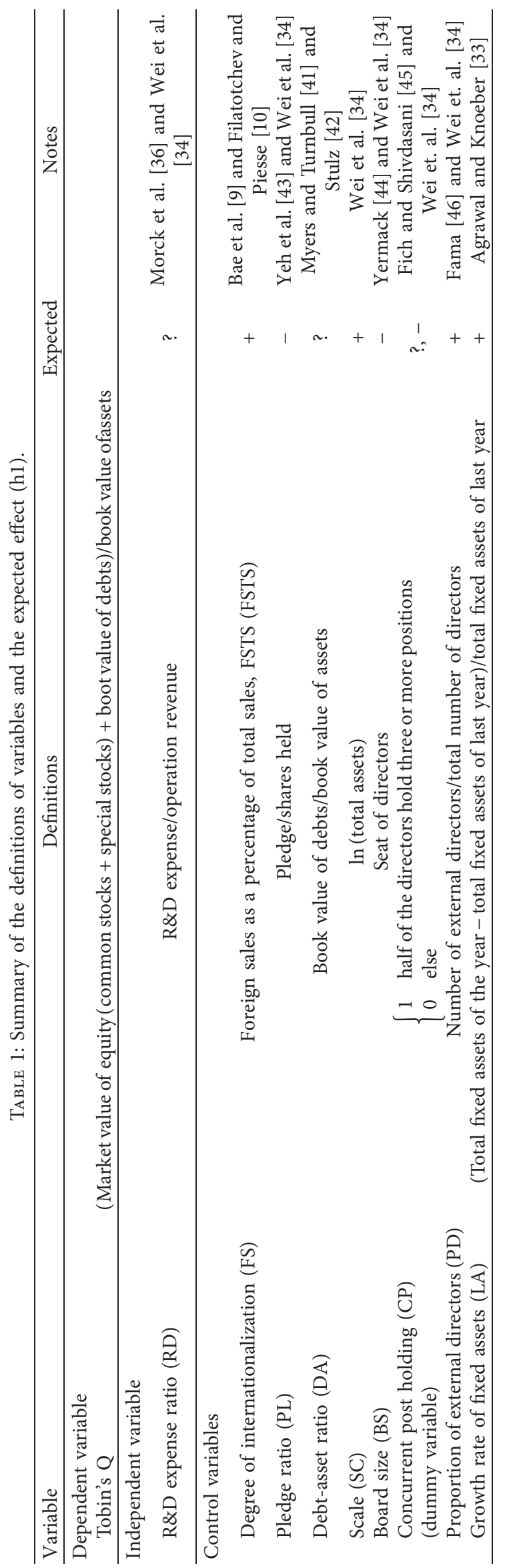


TABLe 2: Descriptive statistics: all samples.

\begin{tabular}{|c|c|c|c|c|c|c|c|c|}
\hline & Obs. & Mean & Median & Maximum & Minimum & Std. dev. & Skewness & Kurtosis \\
\hline Tobin's Q & 27062 & 1.1419 & 0.8700 & 19.8700 & 0.0200 & 0.9110 & 5.3172 & 56.0732 \\
\hline FS & 27062 & 58.8074 & 66.3400 & 116.8700 & 0.0100 & 33.3170 & -0.4025 & 1.7522 \\
\hline SC & 27062 & 14.8145 & 14.6385 & 21.9492 & 9.1441 & 1.4694 & 0.7678 & 4.0716 \\
\hline LA & 27062 & 18.5853 & 1.3267 & 978.2832 & -100.0000 & 72.5033 & 6.0883 & 53.4764 \\
\hline DA & 27062 & 42.5109 & 42.0650 & 1085.1900 & 0.6100 & 22.0216 & 9.7480 & 337.0487 \\
\hline AG & 27062 & 21.7969 & 19.7863 & 71.7178 & 0.0000 & 12.8041 & 0.6784 & 3.0265 \\
\hline BS & 27062 & 8.4779 & 9.0000 & 32.0000 & 0.0000 & 3.3803 & -0.3217 & 6.5628 \\
\hline OB & 27062 & 14.2005 & 11.1111 & 80.0000 & 0.0000 & 15.4073 & 0.5473 & 2.0760 \\
\hline $\mathrm{BP}$ & 27062 & 0.0829 & 0.0000 & 1.0000 & 0.0000 & 0.2758 & 3.0249 & 10.1501 \\
\hline PL & 27062 & 6.3821 & 0.0000 & 100.0000 & 0.0000 & 15.4213 & 3.1325 & 13.6357 \\
\hline $\mathrm{RD}$ & 27062 & 4.8021 & 2.1400 & 182.0600 & 0.0000 & 9.0261 & 5.9517 & 60.6502 \\
\hline MT & 27062 & 6.5997 & 4.5395 & 115.7427 & 0.0000 & 7.5071 & 3.6651 & 24.1263 \\
\hline $\mathrm{ME}$ & 27062 & 6.9498 & 5.0793 & 159.2428 & 0.0000 & 8.2558 & 5.7033 & 57.7411 \\
\hline
\end{tabular}

(3) Firm Age (AG). The firm age of this study refers to the natural firm age, and so, its calculation mode is as follows:

Firm age $=\frac{\text { (Date of data collection }(\text { supposed December } 31 \text { of that year })-\text { date of establishment })}{365}$.

(4) Board Structure. This variable is presented in three forms in this study: board size (BSIZE; BS), ratio of external directors $(\mathrm{PE})$, and concurrent positions of directors $(\mathrm{CP})$.

Scale of board of directors $=$ Total seats of directors,

Ratio of external directors $=\frac{\text { Seats of external directors }}{\text { Total seats of directors }}$.

The concurrent position of directors is a virtual variable. If more than half of the board of directors assume three or more positions (including their position in the sampled company), then the variable is 1 and otherwise 0 .
Due to problematic data acquisition, the definition of positions is mainly those directors and managers present in the annual reports of listed companies.

(5) Proportion of Pledged Shares by Directors (Pledge, PL). This proportion is one of the commonly used indicators for corporate governance. Yeh et al. [43] and Wei et al. [34] argued that the higher the proportion is of pledged shares by major shareholders, the deeper their involvement in the stock market is and the worse the corporate performance will be.

$$
\text { Proportion of pledge shares by directors }=\frac{\text { Quantity of pledge by directors }}{\text { Total shares by all directors }} \text {. }
$$

The estimated impact of the control variables in this study on corporate performance is given in Table 1 .

\section{Empirical Analysis}

In the process of empirical analysis, an analysis of all samples was conducted at first, and then, the samples were divided into three groups, namely, the high Tobin's Q group, the median Tobin's Q group, and the low Tobin's Q group, for separate analysis. Descriptive statistical analysis was conducted at first, followed by correlation matrix analysis and panel data analysis for four groups, namely, all samples, high Tobin's Q (firms with good operating performance), median
Tobin's Q (firms with average operating performance), and low Tobin's Q (firms with poor operating performance), respectively.

3.1. Univariate Analysis. It could be seen from Tables 2-5 that a total of 27,062 samples were used in this study, including 9,026 high Tobin's Q samples, 9,014 median Tobin's Q samples, and 9,022 low Tobin's Q samples. There were no abnormalities in the individual sample groups for other central tendency values (mean value, median value, maximum value, and minimum value), the standard deviation, skewness, or kurtosis. 
TABle 3: Descriptive statistics: high Tobin's Q sample.

\begin{tabular}{|c|c|c|c|c|c|c|c|c|}
\hline & Obs. & Mean & Median & Maximum & Minimum & Std. dev. & Skewness & Kurtosis \\
\hline Tobin's Q & 9026 & 1.9321 & 1.5400 & 19.8700 & 1.0600 & 1.2223 & 4.4990 & 37.5176 \\
\hline FS & 9026 & 62.0142 & 71.0300 & 101.5800 & 0.0100 & 32.6234 & -0.5529 & 1.9291 \\
\hline SC & 9026 & 14.9006 & 14.7252 & 21.4123 & 10.0839 & 1.4263 & 0.8882 & 4.5792 \\
\hline LA & 9026 & 19.3538 & 4.0571 & 975.8097 & -100.0000 & 64.4680 & 6.2535 & 62.4870 \\
\hline DA & 9026 & 35.8457 & 35.0950 & 298.8100 & 0.6100 & 16.8196 & 1.3866 & 15.7805 \\
\hline AG & 9026 & 20.5234 & 18.4781 & 67.5507 & 0.2548 & 11.5492 & 0.8437 & 3.4661 \\
\hline BS & 9026 & 9.4101 & 9.0000 & 32.0000 & 0.0000 & 2.4385 & 2.1171 & 13.3961 \\
\hline OB & 9026 & 19.1764 & 20.0000 & 66.6667 & 0.0000 & 15.6606 & 0.0900 & 1.9270 \\
\hline BP & 9026 & 0.0848 & 0.0000 & 1.0000 & 0.0000 & 0.2785 & 2.9818 & 9.8913 \\
\hline PL & 9026 & 5.3472 & 0.0000 & 99.9900 & 0.0000 & 13.4024 & 3.3548 & 15.7525 \\
\hline $\mathrm{RD}$ & 9026 & 6.1731 & 2.9600 & 155.6500 & 0.0000 & 10.2952 & 4.8538 & 39.2547 \\
\hline MT & 9026 & 7.1081 & 4.6502 & 90.7228 & 0.0000 & 8.4761 & 3.3554 & 18.7769 \\
\hline $\mathrm{ME}$ & 9026 & 7.3302 & 5.2099 & 147.7812 & 0.0000 & 9.2216 & 5.6784 & 53.1456 \\
\hline
\end{tabular}

TABle 4: Descriptive statistics: median Tobin's Q sample.

\begin{tabular}{|c|c|c|c|c|c|c|c|c|}
\hline & Obs. & Mean & Median & Maximum & Minimum & Std. dev. & Skewness & Kurtosis \\
\hline Tobin's Q & 9014 & 0.8834 & 0.8700 & 1.0600 & 0.7600 & 0.0798 & 0.4066 & 2.2004 \\
\hline FS & 9014 & 55.7081 & 60.1750 & 116.8700 & 0.0100 & 33.1541 & -0.2558 & 1.6724 \\
\hline SC & 9014 & 14.6911 & 14.5091 & 21.0457 & 9.1441 & 1.4682 & 0.6865 & 3.6706 \\
\hline LA & 9014 & 19.8439 & 1.3769 & 970.5067 & -99.6874 & 75.1988 & 5.9728 & 50.7285 \\
\hline DA & 9014 & 43.5365 & 43.9000 & 1085.1900 & 1.1900 & 22.4311 & 13.0991 & 557.1605 \\
\hline $\mathrm{AG}$ & 9014 & 21.3079 & 19.2767 & 71.7178 & 0.0000 & 13.2524 & 0.7058 & 3.0239 \\
\hline BS & 9014 & 8.0485 & 9.0000 & 32.0000 & 0.0000 & 3.6866 & -0.4904 & 5.1099 \\
\hline OB & 9014 & 11.7903 & 0.0000 & 80.0000 & 0.0000 & 14.6663 & 0.7960 & 2.4019 \\
\hline BP & 9014 & 0.0818 & 0.0000 & 1.0000 & 0.0000 & 0.2740 & 3.0528 & 10.3197 \\
\hline PL & 9014 & 6.4446 & 0.0000 & 99.9800 & 0.0000 & 15.3765 & 3.0836 & 13.3954 \\
\hline $\mathrm{RD}$ & 9014 & 4.9047 & 2.0500 & 182.0600 & 0.0000 & 9.6932 & 6.2541 & 67.1391 \\
\hline MT & 9014 & 6.4773 & 4.4778 & 115.7427 & 0.0000 & 7.3672 & 3.9116 & 29.9393 \\
\hline $\mathrm{ME}$ & 9014 & 7.2849 & 5.1547 & 159.2428 & 0.0000 & 8.9769 & 5.4092 & 51.0742 \\
\hline
\end{tabular}

Table 5: Descriptive statistics: low Tobin's Q sample.

\begin{tabular}{|c|c|c|c|c|c|c|c|c|}
\hline & Obs. & Mean & Median & Maximum & Minimum & Std. dev. & Skewness & Kurtosis \\
\hline Tobin's Q & 9022 & 0.6097 & 0.6300 & 0.7600 & 0.0200 & 0.1170 & -1.1662 & 4.8145 \\
\hline FS & 9022 & 58.6958 & 66.8550 & 111.5000 & 0.0100 & 33.8664 & -0.4064 & 1.7232 \\
\hline SC & 9022 & 14.8517 & 14.6726 & 21.9492 & 10.0579 & 1.5047 & 0.7569 & 3.9871 \\
\hline LA & 9022 & 16.5591 & -0.5734 & 978.2832 & -100.0000 & 77.1682 & 5.9896 & 48.9766 \\
\hline $\mathrm{DA}$ & 9022 & 48.1543 & 47.6800 & 784.8800 & 0.9700 & 24.3241 & 10.5755 & 261.5186 \\
\hline $\mathrm{AG}$ & 9022 & 23.5595 & 22.0658 & 71.7178 & 0.0000 & 13.3383 & 0.4860 & 2.7161 \\
\hline BS & 9022 & 7.9743 & 8.0000 & 29.0000 & 0.0000 & 3.6661 & -0.4642 & 4.8901 \\
\hline $\mathrm{OB}$ & 9022 & 11.6304 & 0.0000 & 80.0000 & 0.0000 & 14.6507 & 0.8282 & 2.4939 \\
\hline $\mathrm{BP}$ & 9022 & 0.0822 & 0.0000 & 1.0000 & 0.0000 & 0.2748 & 3.0412 & 10.2486 \\
\hline PL & 9022 & 7.3551 & 0.0000 & 100.0000 & 0.0000 & 17.1885 & 2.9213 & 11.7657 \\
\hline $\mathrm{RD}$ & 9022 & 3.3278 & 1.6000 & 133.4300 & 0.0000 & 6.3575 & 7.2162 & 93.1278 \\
\hline MT & 9022 & 6.2133 & 4.4909 & 79.9895 & 0.0000 & 6.5216 & 3.6208 & 23.6640 \\
\hline ME & 9022 & 6.2343 & 4.8765 & 120.4954 & 0.0000 & 6.1729 & 4.9621 & 55.0603 \\
\hline
\end{tabular}

3.2. Bivariate Analysis. Tables 6-9 set forth the correlation coefficients among variables. There was generally no high correlation among the explanatory variables (extent of internationalization, moderating variables, and control variables). Therefore, the issue of collinearity was not encountered during the analysis.

In respect of the correlation among variables, a positive correlation was observed between extent of internationalization and three of the four Tobin's Q sample groups, and a negative correlation was observed only with the low Tobin's Q firms. There were also different positive and negative correlations between other variables and Tobin's Q. Therefore, the ultimate impact results could be obtained through further discussion based on regression analysis.

3.3. All-Sample Analysis. An analysis of all samples was conducted in three categories, namely, explanatory variable $(\mathrm{EV})$ analysis, control variable $(\mathrm{CV})$ analysis, and all variable 


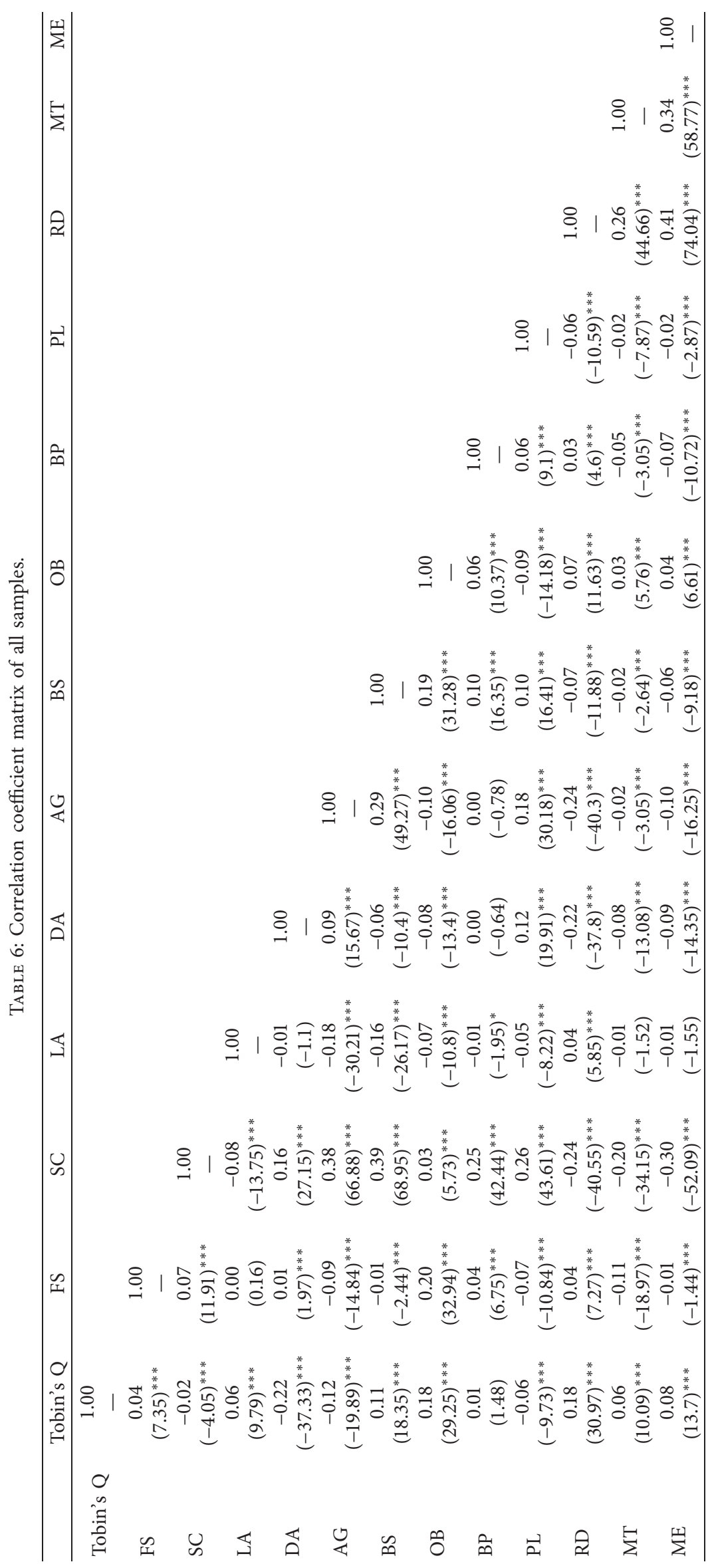




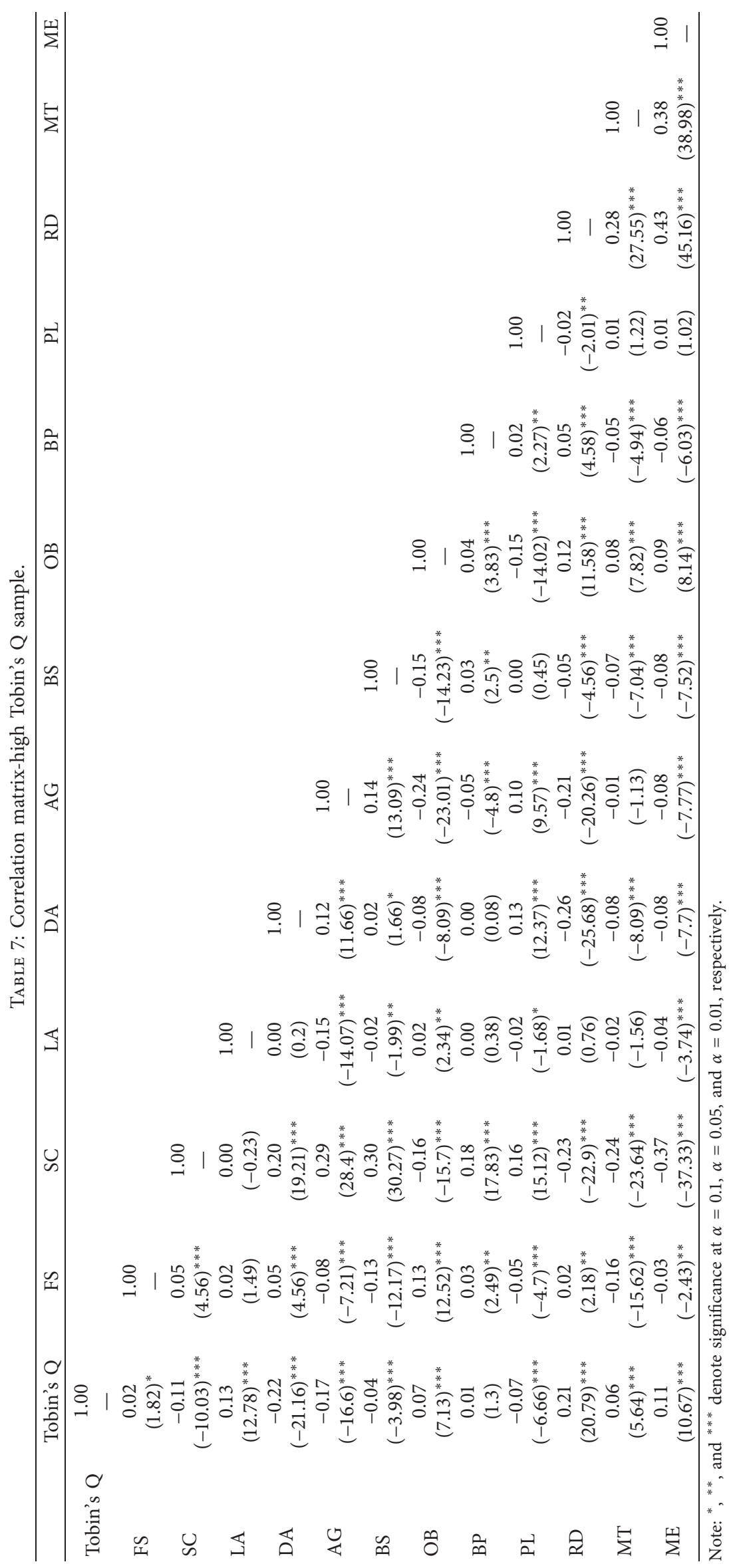




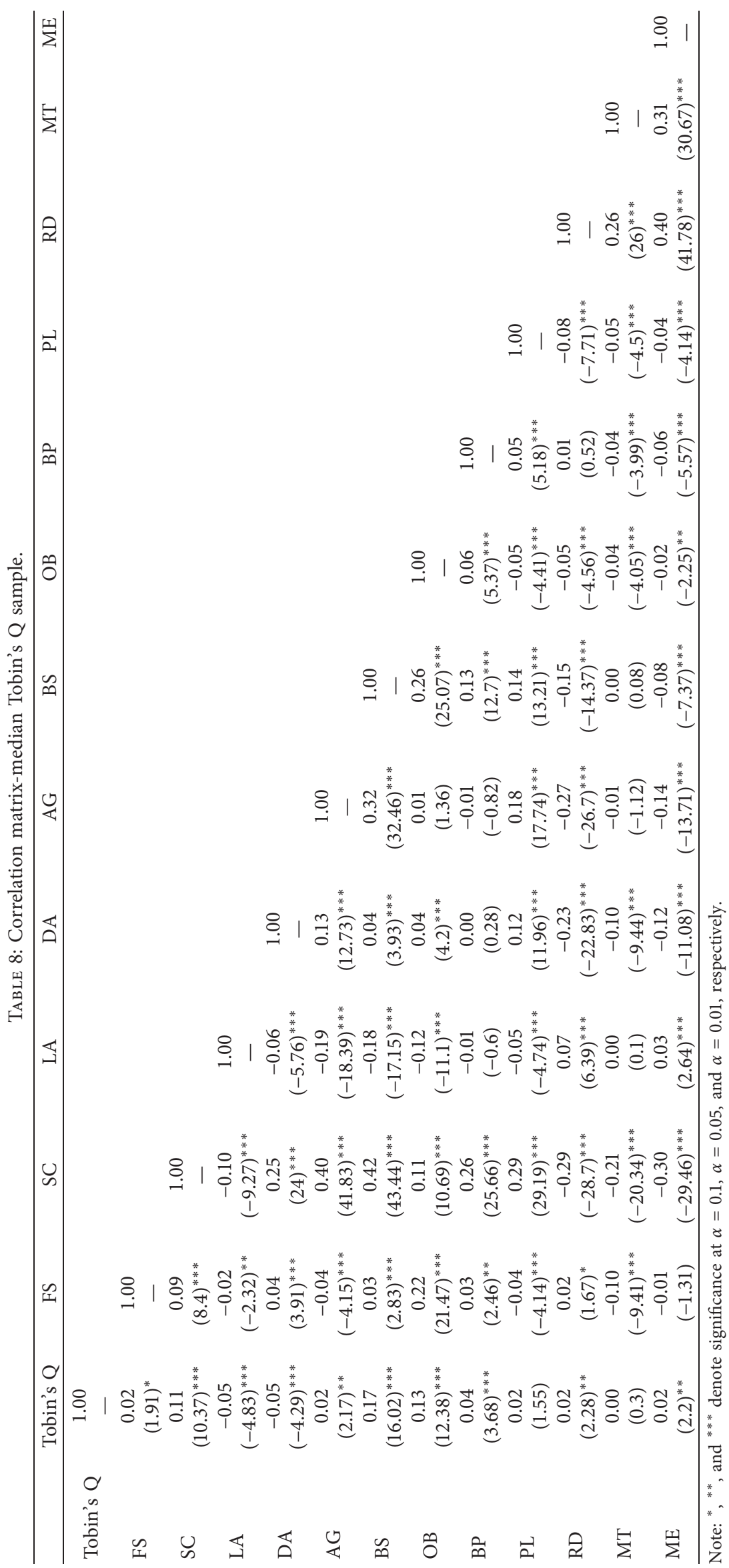




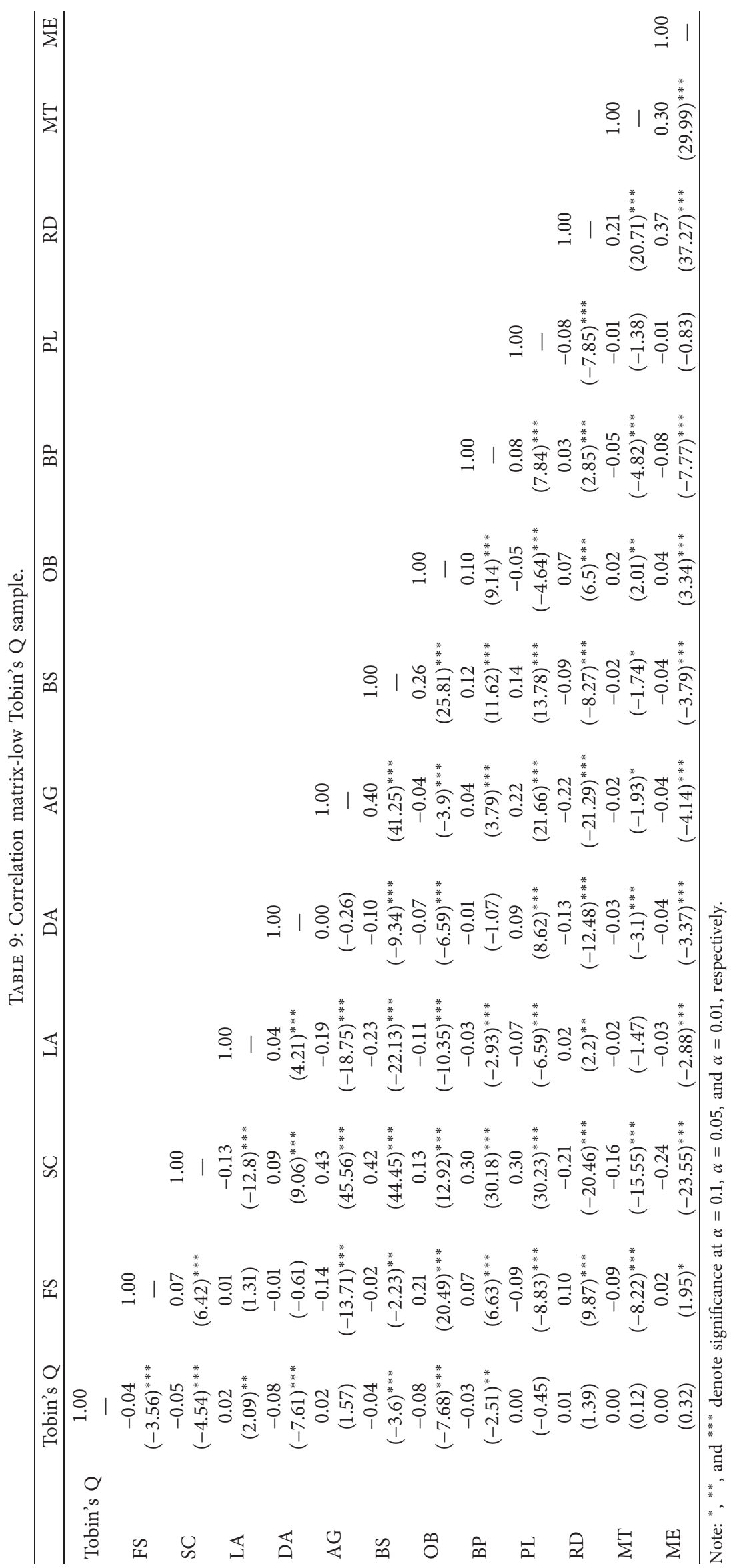




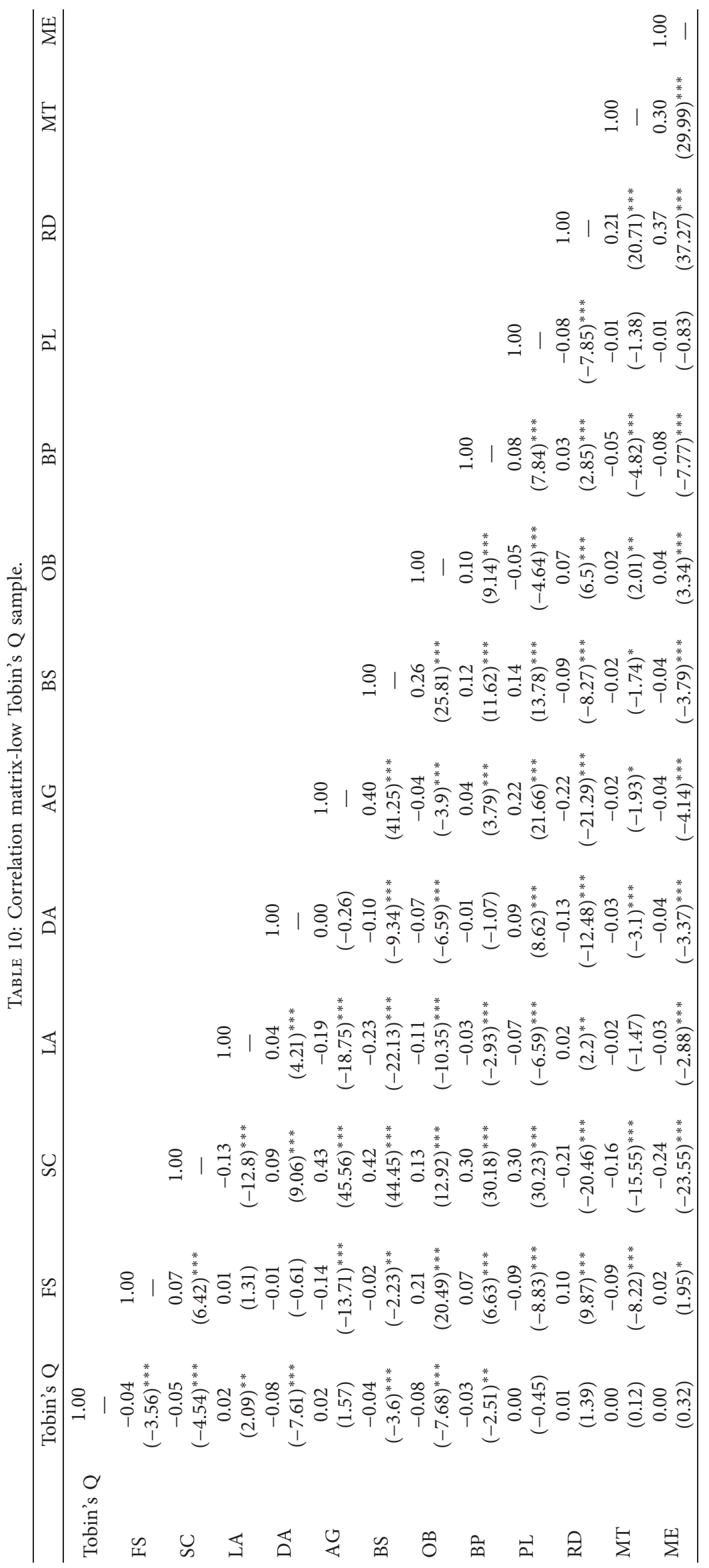


TABLe 11: Pooled regression model.

\begin{tabular}{lcccccr}
\hline & \multicolumn{3}{c}{ Unweighted } & \multicolumn{3}{c}{ Weighted } \\
& EV & CV & AV & EV & CV & AV \\
\hline$R^{2}$ & 0.0022 & 0.1114 & 0.1118 & 0.0024 & 0.2311 & 0.1944 \\
SSE & 22498 & 19956 & 19948 & 19085 & 17810 & 17801 \\
\hline
\end{tabular}

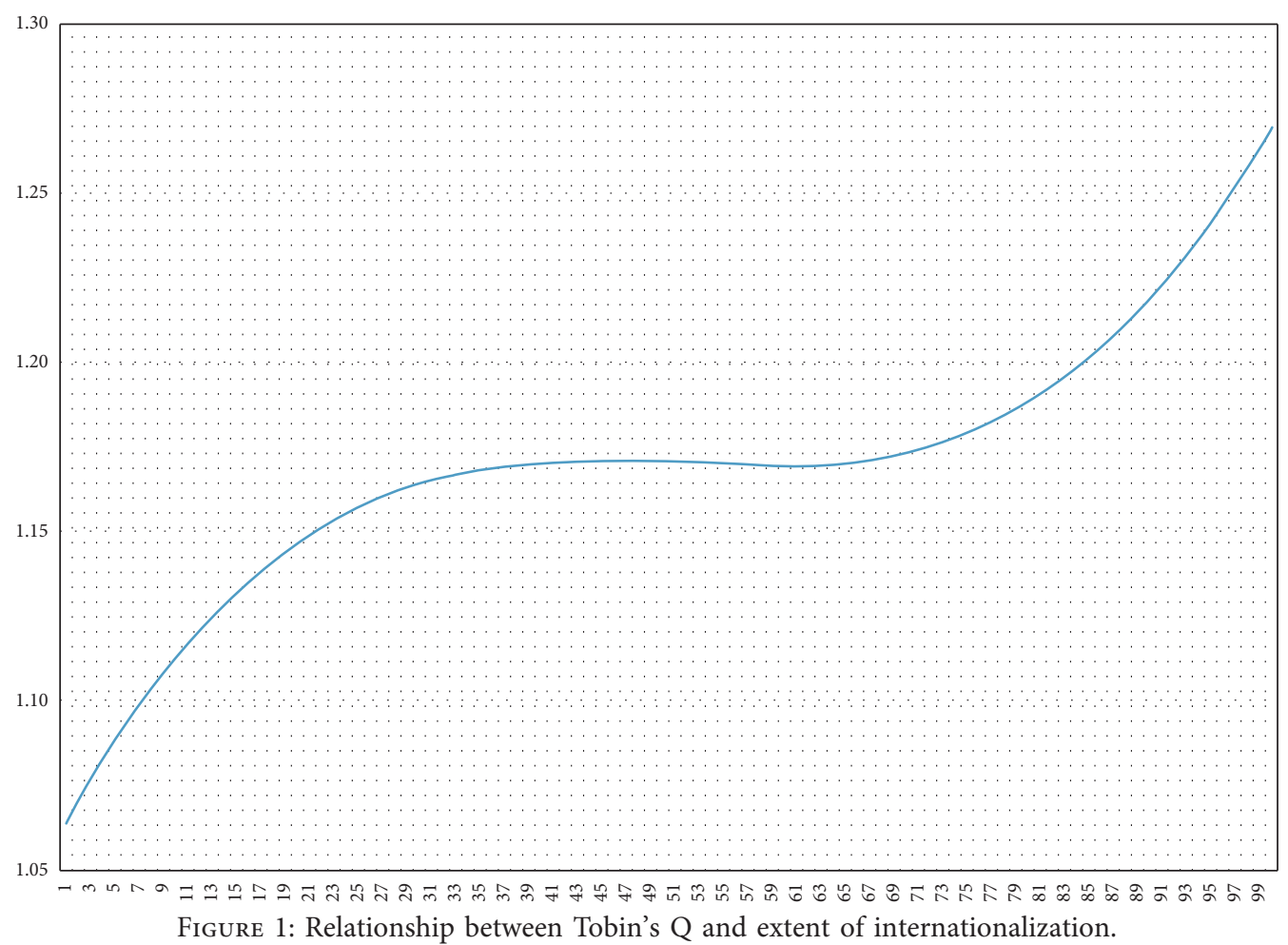

$(\mathrm{AV})$ analysis. The analysis results are given in Tables 10 and 11.

It can be seen from Table 10 that $R^{2}$ and SSE of the three categories of regression analysis were significant in the pooled regression model $(0.0024,0.2311$, and 0.1944 and 19085,17810 , and 17801, respectively); therefore, panel data analysis was applicable to the three categories.

According to Table 11, the Hausman test found that for the model comprised of explanatory variables, the $p$ value $=0.0912>0.05$; therefore, it was appropriate to interpret using the random effect model, while the fixed effect model was most applicable to the others.

It can be seen from the above model that internationalization has a S-shaped impact on firm performance, as shown in Figure 1.

It could be clearly seen that the impact of extent of internationalization on Tobin's Q was divided into three stages; a significant impact on firm performance was observed in the early stage of internationalization, there was no contribution in stage 2 , and a significant positive impact was observed again in the final stage.

It could be seen from the above regression equation that extent of internationalization indeed had a positive S-shaped impact on firm performance. In addition, all control variables applied in this study had a significant impact on firm performance, among which SC (0.0238), LA (0.0009), BS (0.0355), OB (0.0067), RD (0.0117), MT (0.0028), and ME $(0.0021)$ showed a positive significant impact, while DA (-0.0069), AG (-0.0076), BP (-0.0654), and PL (-0.0008) showed a negative significant impact.

3.4. High Tobin's Q Sample Analysis. As stated in the introduction, the impact of the extent of internationalization will vary with firm performance. Therefore, analysis of the high Tobin's Q samples was conducted in this study for further discussion on the impact of extent of internationalization on firm performance. The analysis results are given in Table 12.

It was found through analysis on whether the panel data analysis was applicable that $R^{2}$ and SSE $(0.3928$, 10934) of the pooled regression model were more significant than those of the general regression model $(0.1052,12064)$. Therefore, panel data analysis was also applicable to the samples with a high Tobin's Q. The Hausman test results also showed that the fixed effect model was most appropriate for interpretation of this model. 


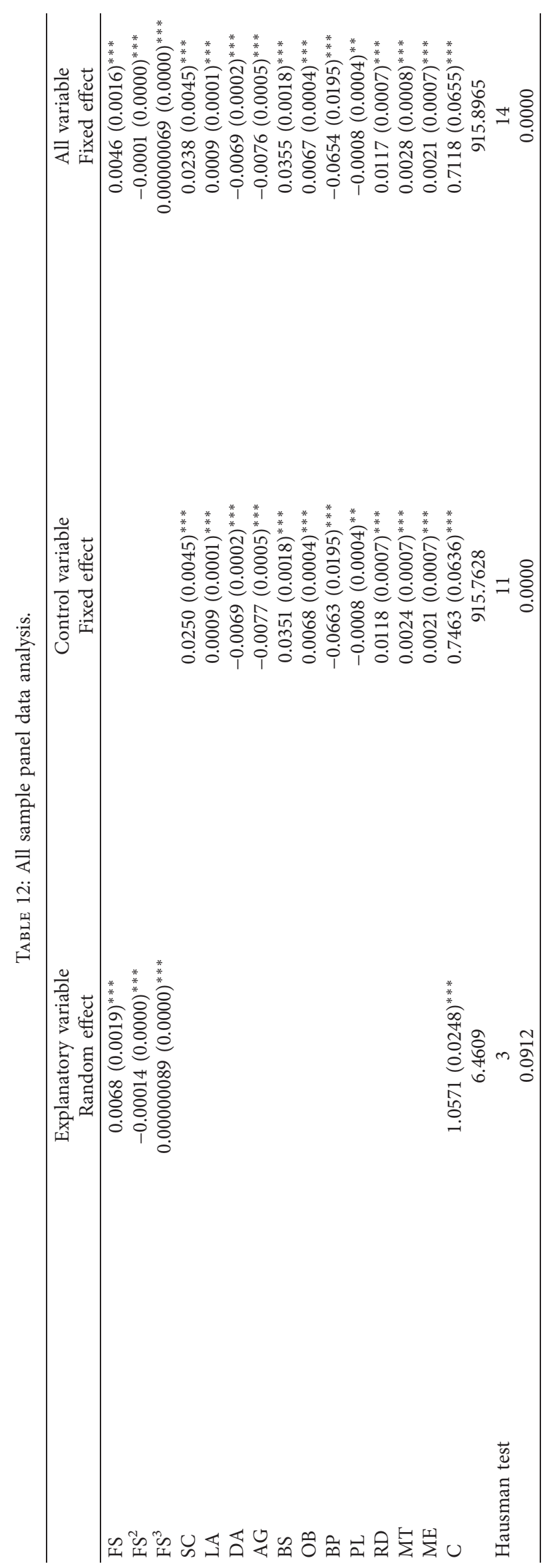




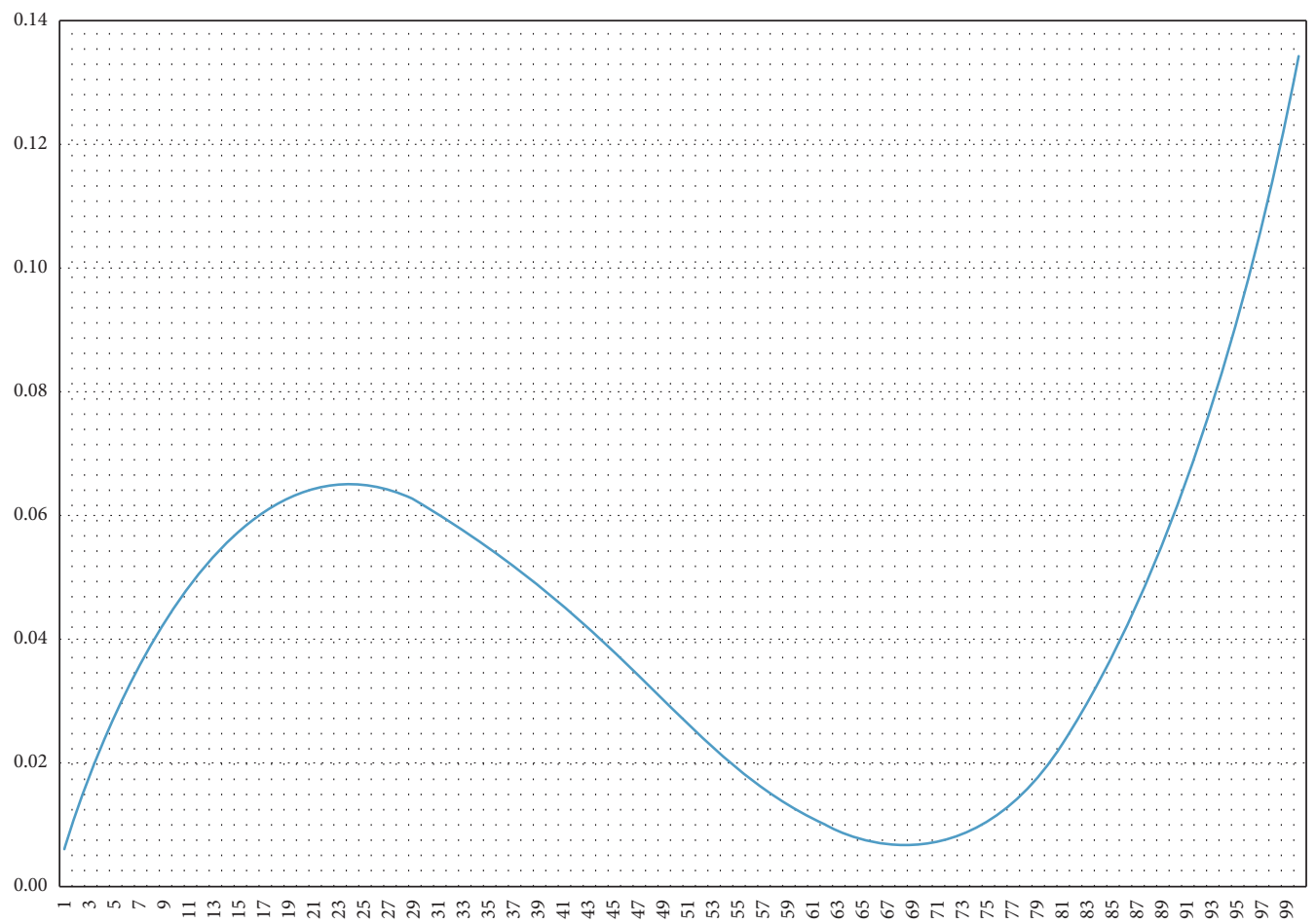

FIgURE 2: Relationship between high Tobin's Q and extent of internationalization.

TABle 13: High Tobin's Q panel data analysis.

\begin{tabular}{lcc}
\hline & Pooled regression & \\
Unweighted & \\
SSE & 0.1052 & 0.3928 \\
Hausman test & 12064 & 10934 \\
Fixed effect & & 14.0000 \\
FS & 0.0000 \\
FS & \\
FS & & $0.0062(0.0030)^{*}$ \\
SC & & $-0.000178(0.0001)^{*}$ \\
LA & & $0.00000129(0.0000)^{* *}$ \\
DA & $0.0069(0.0104)$ \\
AG & & $0.0023(0.0002)^{* * *}$ \\
BS & $-0.0121(0.0008)^{* * *}$ \\
OB & $-0.0117(0.0012)^{* * *}$ \\
BP & $-0.0049(0.0053)$ \\
PL & & $0.0010(0.0010)$ \\
RD & & $0.0263(0.0446)$ \\
MT & & $-0.0040(0.0009)^{* * *}$ \\
ME & & $0.0159(0.0014)^{* * *}$ \\
C & $-0.0004(0.0016)$ \\
\hline
\end{tabular}

It was found that the extent of internationalization had a quadratic significant negative impact on the high Tobin's Q samples and a linear and cubic significant positive impact. Contributions of 0.0062 FS -0.000178 FS2 + 0.00000129FS3 to Tobin's Q are shown in Figure 2, from which it could be seen that the impact of extent of internationalization on the high Tobin's Q samples was different from its impact on all samples. When internationalization reached a certain extent, for the samples with a high Tobin's Q, a decrease in Tobin's $\mathrm{Q}$ would be caused by increasing the extent of internationalization (by approximately $25 \%$ ), and a rise in Tobin's Q would be caused at last (by approximately 75\%).

For the other control variables, it was found that LA (0.0023), RD (0.0159), and ME (0.0052) had a significant 
TABLE 14: Median Tobin's Q pooled regression analysis.

\begin{tabular}{|c|c|c|c|c|c|c|}
\hline & \multicolumn{3}{|c|}{ Unweighted } & \multicolumn{3}{|c|}{ Weighted } \\
\hline$\overline{R^{2}}$ & 0.0478 & 0.0478 & 0.0477 & 0.4505 & 0.4460 & 0.3978 \\
\hline SSE & 54.6773 & 54.6804 & 54.6876 & 54.5481 & 54.5622 & 54.5725 \\
\hline
\end{tabular}

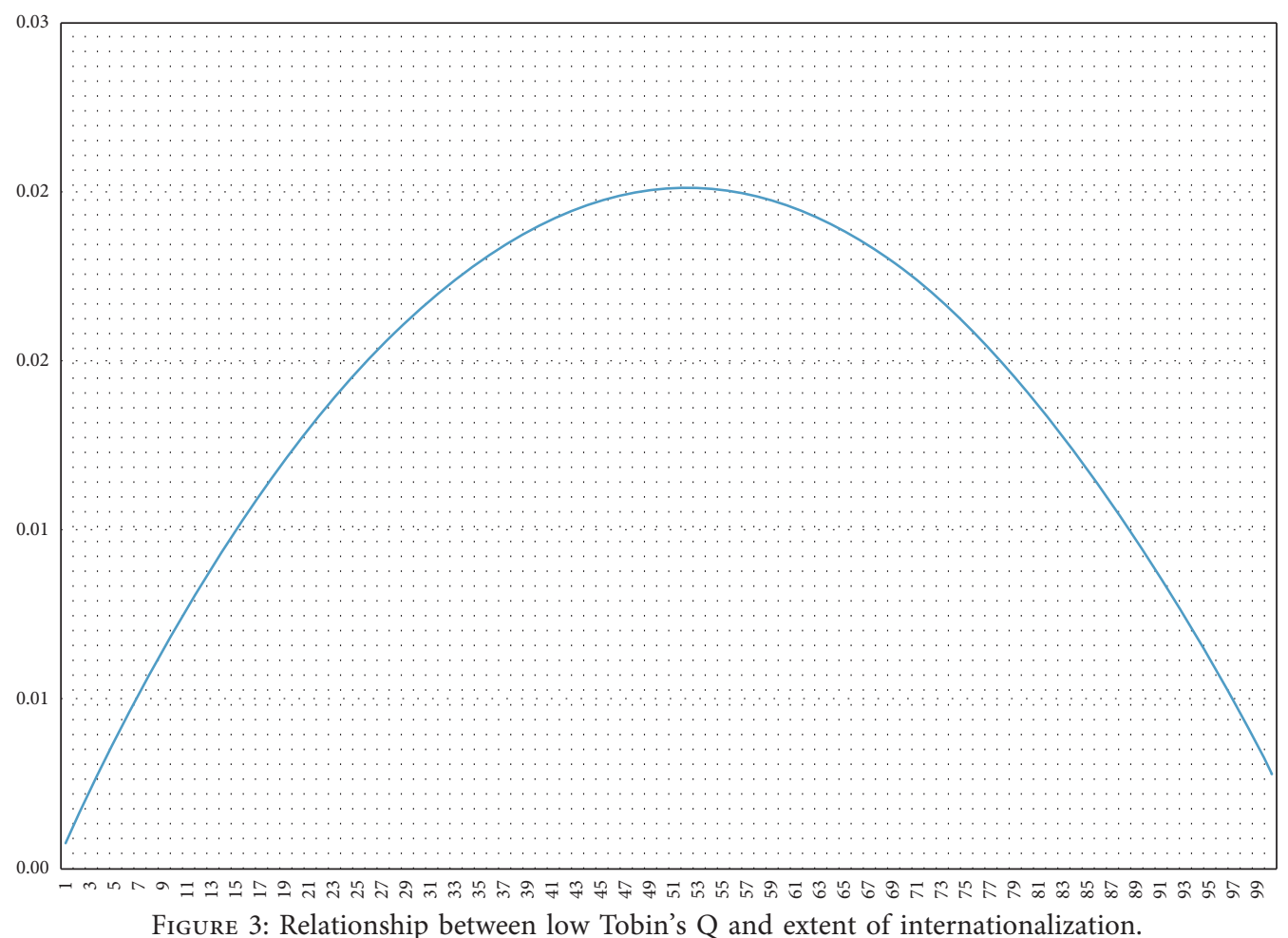

TABle 15: Median Tobin's Q sample panel data analysis.

\begin{tabular}{lccc}
\hline Variable & Fixed effect & Fixed effect & Fixed effect \\
\hline FS & $-0.000260(0.0003)$ & $-0.000141(0.0001)$ & $-0.000053(0.0000)^{* *}$ \\
FS & $0.0000039(0.0000)$ & $0.0000009(0.0000)$ & \\
FS & $-0.00000002(0.0000)$ & $0.0052(0.0008)^{* * *}$ & $0.0052(0.0007)^{* * *}$ \\
SC & $0.0052(0.0008)^{* * *}$ & $-0.000017(0.0000)$ & $-0.000017(0.0000)$ \\
LA & $-0.000017(0.0000)$ & $-0.0002(0.0000)^{* * *}$ & $-0.0002(0.0000)^{* * *}$ \\
DA & $-0.0002(0.0000)^{* * *}$ & $-0.0003(0.0001)^{* * *}$ & $-0.0003(0.0001)^{* * *}$ \\
AG & $-0.0003(0.0001)^{* * *}$ & $0.0028(0.0003)^{* * *}$ & $0.0028(0.0003)^{* * *}$ \\
BS & $0.0028(0.0003)^{* * *}$ & $0.0004(0.0001)^{* * *}$ & $0.0004(0.0001)^{* * *}$ \\
OB & $0.0004(0.0001)^{* * *}$ & $-0.0015(0.0032)$ & $-0.0016(0.0032)$ \\
BP & $-0.0015(0.0032)$ & $-0.000029(0.0001)$ & $-0.000029(0.0001)$ \\
PL & $-0.000029(0.0001)$ & $0.0003(0.0001)^{* * *}$ & $0.0003(0.0001)^{* * *}$ \\
RD & $0.0003(0.0001)^{* * *}$ & $-0.000009(0.0001)$ & $0.000003(0.0001)$ \\
MT & $-0.000016(0.0001)$ & $0.0003(0.0001)^{* * *}$ & $0.0003(0.0001)^{* * *}$ \\
ME & $0.0003(0.0001)^{* * *}$ & $0.7971(0.0106)^{* * *}$ & $0.7953(0.0104)^{* * *}$ \\
C & $0.7978(0.0107)^{* * *}$ & 30.0427 & 23.6662 \\
Hausman test & 31.2086 & 13 & 12 \\
& 14 & 0.0046 & 0.0226 \\
\hline
\end{tabular}

positive impact on firm performance, while DA $(-0.0121)$, AG $(-0.0117)$, and PL $(-0.0040)$ had a significant negative impact on firm performance.
3.5. Median Tobin's Q Sample Analysis. In respect of the median Tobin's Q analysis, it was found through analysis based on the nonlinear regression equation that the cubic 
TABLE 16: Low Tobin's Q pooled regression analysis.

\begin{tabular}{lcccc}
\hline & \multicolumn{3}{c}{ Unweighted } & \multicolumn{2}{c}{ Weighted } \\
\hline$R^{2}$ & 0.0199 & 0.0197 & 0.2662 & 0.0954 \\
SSE & 120.9696 & 120.9950 & 118.5360 & 118.3612 \\
\hline
\end{tabular}

TABLE 17: Low Tobin's Q sample panel data analysis.

\begin{tabular}{lcr}
\hline & Fixed effect & Fixed effect \\
\hline FS & $0.0004(0.0004)$ & $0.0008(0.0001)^{* * *}$ \\
FS $^{2}$ & $0.0000028(0.0000)$ & $-0.0000075(0.0000)^{* * *}$ \\
FS & $-0.00000007(0.0000)$ & $-0.0011(0.0011)$ \\
SC & $-0.0010(0.0011)$ & $0.000015(0.0000)$ \\
LA & $0.000015(0.0000)$ & $-0.0005(0.0001)^{* * *}$ \\
DA & $-0.0005(0.0001)^{* * *}$ & $0.0003(0.0001)^{* * *}$ \\
AG & $0.0003(0.0001)^{* * *}$ & $0.0002(0.0004)$ \\
BS & $0.0001(0.0004)$ & $-0.0004(0.0001)^{* * *}$ \\
OB & $-0.0004(0.0001)^{* * *}$ & $-0.0052(0.0046)$ \\
BP & $-0.0053(0.0046)$ & $0.0001(0.0001)$ \\
PL & $0.0001(0.0001)$ & $0.0002(0.0002)$ \\
RD & $0.0002(0.0002)$ & $0.00001(0.0002)$ \\
MT & $-0.00001(0.0002)$ & $0.00003(0.0002)$ \\
ME & $0.00003(0.0002)$ & $0.6325(0.0155)^{* * *}$ \\
C & $0.6344(0.0156)^{* * *}$ & 34.8362 \\
Hausman test & 34.9369 & 13.0000 \\
\end{tabular}

TABLE 18: Summary of the impact of control variables on firms with a high, median, and low Tobin's Q.

\begin{tabular}{lcccc}
\hline & All & High & Median & + \\
\hline SC & + & & Low \\
LA & + & + & - & + \\
DA & - & - & & + \\
AG & - & & + \\
BS & + & - & + \\
OB & + & + & + \\
BP & - & + & + \\
PL & - & + & + \\
RD & + & + & & + \\
MT & + & + & \\
ME & + & & + \\
\hline
\end{tabular}

and quadratic factors showed an insignificant impact. It was found through linear regression analysis that extent of internationalization only had a linear impact on the median Tobin's Q samples. The analysis results are given in Tables 13 and 14. A linear fixed effect model of internationalization was the most applicable model for interpretation.

It was found from the samples with a median Tobin's Q that extent of internationalization had a negative significant effect on firm performance $(-0.000053)$; however, in respect of the control variables, SC (0.0052), BS (0.0028), OB (0.0004), RD (0.0003), and ME (0.0003) showed a significant positive effect, while DA $(-0.0002)$ and AG (-0.0003) showed a significant negative effect. All other variables showed an insignificant effect.

3.6. Low Tobin's Q Sample Analysis. It could be seen from the above equation that for the samples with a low Tobin's $Q$, the extent of internationalization had an inverted U-shaped relationship with firm performance. 0.0008 FS -0.0000075 FS2 analysis results are shown in Figure 3, from which it could be seen that an improvement of the extent of internationalization by approximately $50 \%$ started to have a negative impact on firm performance (Tables 15 and 16). 
In respect of the control variables, only DA $(-0.0005)$, AG (0.0003), and OB (-0.0004) showed a significant impact on firm performance; the other variables showed an insignificant impact.

\section{Conclusion}

The process of empirical analysis is rigorous. The most commonly overlooked and unresolved issue by general research scholars is consistency. There are many ways to resolve inconsistencies. One of them is panel data analysis. This study uses Taiwan 1992. There were 9022 research samples of listed companies in 2017, which are big data analysis. Therefore, panel data analysis is used for analysis, and company performance is divided into high, medium, and low to explore different companies' performance. The degree of internationalization is the company's performance.

Prior research studies on the impact of the extent of internationalization on firm performance produced varying results due to being based on different countries and different industries and included positive and negative effects, as well as U-shaped or inverted U-shaped effects and S-shaped acceleration effects. The impact of internationalization on the performance of listed firms during the period from 1992 to 2017 in Taiwan was discussed for the first time in this study; the research results showed that upon entering developed countries, and internationalization showed an S-shaped acceleration effect on the performance of Taiwanese firms.

It was found that through classified data analysis, the extent of internationalization had significantly different effects on firm performance. The results indicated an S-shaped effect on firms with a high Tobin's Q and an inverted U-shaped effect on firms with a low Tobin's Q, indicating that when internationalization reached a certain extent, a higher extent of internationalization would have a negative impact on firm performance. For firms with a median Tobin's Q, a higher extent of internationalization would have a negative significant effect on firm performance.

The results of this study demonstrated the three-stage theory of internationalization. However, the circumstances in such three stages in Taiwan are different from those stated by previous scholars. As Taiwan is featured by an exportoriented economy, internationalization in the early stage will have a positive impact on the performance of most firms, but it will have a negative impact on firm performance and performance will start to decline upon reaching a certain extent of internationalization, as firms will have to invest substantial costs in internationalization (such as employees, equipment acquisition, internal management systems, and external corporate networks) as well as the increase in learning costs and deficiencies in economies of scale.

In stage 3, however, with the increase in the extent of internationalization, the accumulation of knowledge and experience regarding international operations, and the benefits of internationalization, a positive correlation between internationalization and performance can be observed, and performance improvement is recorded due to the increase in and development of corporate resources, the internalization of transaction costs, the realization of economies of scale and scope, the extended lifetime of products, the acquisition of low-cost resources, and other factors. As industries in Taiwan are dominated by the electronics industry with a high technological level, a higher extent of internationalization in the final stage will make a greater contribution to firm performance; however, for industries with a low technological level, a higher extent of internationalization will lead to significantly poor performance. That is to say, the continuous increase in the extent of internationalization will lead to more complicated international operations and increased management and coordination costs, hence resulting in diminishing performance. Therefore, the extent of internationalization still depends on internal corporate conditions. Firms with weak competitiveness will be unable to make up for the costs of internationalization with the benefits of internationalization.

In this study, the impact of relevant control variables on firm performance was set out in Table 17.

For firms with a high, median, and low Tobin's Q, the debt-asset ratio had a negative significant impact on firm performance. The all-sample analysis indicated that firm age had a negative significant effect on the performance of firms with a high and median Tobin's Q but had a positive effect on the performance of firms with a low Tobin's Q. This result indicated that firms with a low Tobin's Q live off their past gains due to poor management. The $\mathrm{R} \& \mathrm{D}$ expense ratio also showed a positive impact on the performance of firms with a high or median Tobin's Q but showed no impact on firms with a low Tobin's $\mathrm{Q}$, which also indicated that $\mathrm{R} \& \mathrm{D}$ investment would not help due to the poor management of firms with a low Tobin's Q. This result also indicated that the poor management of firms could be mainly attributable to human resources and system-related issues (for example, independent directors and supervisors generally showed a positive effect, while the low Tobin's Q firms showed a negative effect, and the management expense ratio (human resources) showed a positive effect on the high and median Tobin's Q firms but had no impact on the low Tobin's Q firms). Efforts have to be made in these two aspects if improvement is to be achieved. The scale of a company only showed a positive effect on the performance of the median Tobin's Q firms and had no significant effect on the performance of the high Tobin's Q firms or low Tobin's Q firms. In respect of the investment in assets, the increase in the investment in fixed assets of the firms with a high Tobin's $Q$ showed a positive effect and no significant effect for the other two types of firms. In respect of the proportion of pledged shares by directors, a higher proportion of pledged shares by directors had a negative effect on the firms with a high Tobin's Q, which indicated that the directors of firms with a high Tobin's Q have foresight. Table 18

The main findings of this study included the demonstration of different effects of control variables, in addition to the different effects of internalization on firm performance. Therefore, in discussing corporate management, classified data analysis is of great importance. However, the improvement of corporate management should not solely rely on corporate data; improvements should be implemented 
based on corporate characteristics and conditions, so as to yield better results with less effort.

\section{Data Availability}

The data used to support the findings of this study are from listed companies in Taiwan.

\section{Conflicts of Interest}

The authors declare that they have no conflicts of interest.

\section{References}

[1] J. Michael Geringer, P. W. Beamish, and R. C. DaCosta, "Diversification strategy and internationalization: implications for mne performance," Strategic Management Journal, vol. 10, no. 2, pp. 109-119, 1989.

[2] G. G. Dess, A. Gupta, J.-F. Hennart, and C. W. L. Hill, "Conducting and integrating strategy research at the international, corporate, and business levels: issues and directions," Journal of Management, vol. 21, no. 3, pp. 357-393, 1995.

[3] A. Delios and P. W. Beamish, "Geographic scope, product diversification, and the corporate performance of Japanese firms," Strategic Management Journal, vol. 20, no. 8, pp. 711-727, 1999.

[4] R. M. Grant, "Multinationality and performance among british manufacturing companies," Journal of International Business Studies, vol. 18, no. 3, pp. 79-89, 1987.

[5] M. Kotabe, S. S. Srinivasan, and P. S. Aulakh, "Multinationality and firm performance: the moderating role of $\mathrm{R} \& \mathrm{D}$ and marketing capabilities," Journal of International Business Studies, vol. 33, no. 1, pp. 79-97, 2002.

[6] L. Gomes and K. Ramaswamy, "An empirical examination of the form of the relationship between multinationality and performance," Journal of International Business Studies, vol. 30, no. 1, pp. 173-187, 1999.

[7] J. M. Geringer, S. Tallman, and D. M. Olsen, "Product and international diversification among Japanese multinational firms," Strategic Management Journal, vol. 21, no. 1, pp. 51-80, 2000.

[8] M. I. Kafouros, P. J. Buckley, J. A. Sharp, and C. Q. Wang, "The role of internationalization in explaining innovation performance," Technovation, vol. 28, no. 1-2, pp. 63-74, 2008.

[9] S. C. Bae, B. J. C. Park, and X. Wang, "Multinationality, R\&D intensity, and firm performance: evidence from U.S. manufacturing firms," Multinational Business Review, vol. 16, no. 1, pp. 53-78, 2008.

[10] I. Filatotchev and J. Piesse, "R\&D, internationalization and growth of newly listed firms: European evidence," Journal of International Business Studies, vol. 40, no. 8, pp. 1260-1276, 2009.

[11] R. E. Caves, Multinational Enterprise and Economic Analysis, Cambridge University Press, Cambridge, UK, 1982.

[12] L. Franko, “Global corporate competition: who's winning, who's losing, and the R\&D factor as one reason why," Strategic Management Journal, vol. 10, no. 2, pp. 49-74, 1989.

[13] D. Sullivan, "Measuring the degree of internationalization of a firm," Journal of International Business Studies, vol. 25, no. 2, pp. 325-342, 1994.

[14] D. J. Eppink and B. M. Van Rhijn, "The internationalization of Dutch insurance companies," Long Range Planning, vol. 21, no. 5, pp. 54-60, 1988.
[15] M. A. Hitt, R. E. Hoskisson, and H. Kim, "International diversification: effects on innovation and firm performance in product-diversified firms," Academy of Management Journal, vol. 40, no. 4, pp. 767-798, 1997.

[16] M. A. Hitt, R. E. Hoskisson, and R. D. Ireland, “A mid-range theory of the interactive effects of international and product diversification on innovation and performance," Journal of Management, vol. 20, no. 2, pp. 297-326, 1994.

[17] F. J. Contractor, S. K. Kundu, and C.-C. Hsu, "A three-stage theory of international expansion: the link between multinationality and performance in the service sector," Journal of International Business Studies, vol. 34, no. 1, pp. 5-18, 2003.

[18] J. W. Lu and P. W. Beamish, "The internationalization and performance of SMEs," Strategic Management Journal, vol. 22, no. 6/7, pp. 565-586, 2001.

[19] V. R. Errunza and L. W. Senbet, "International corporate diversification, market valuation, and size-adjusted evidence," The Journal of Finance, vol. 39, no. 3, pp. 727-743, 1984.

[20] Y. Chen, R.-R. Zhai, C. Wang, and C. Zhong, "Home institutions, internationalization and firm performance: evidence from listed Chinese firms," Management Decision, vol. 53, no. 1, pp. 160-178, 2015.

[21] C. Zhou, "Internationalization and performance: evidence from Chinese firms," Chinese Management Studies, vol. 12, no. 1, pp. 19-34, 2018.

[22] H. Kim, J. Wu, D. A. Schuler, and R. E. Hoskisson, "Chinese multinationals' fast internationalization: financial performance advantage in one region, disadvantage in another," Journal of International Business Studies, vol. 51, no. 7, pp. 1076-1106, 2020.

[23] M. D. R. Chari, S. Devaraj, and P. David, "International diversification and firm performance: role of information technology investments," Journal of World Business, vol. 42, no. 2, pp. 184-197, 2007.

[24] P. Dastidar, "International corporate diversification and performance: does firm self-selection matter?" Journal of International Business Studies, vol. 40, no. 1, pp. 71-85, 2009.

[25] Y. Fang, M. Wade, A. Delios, and P. W. Beamish, "International diversification, subsidiary performance, and the mobility of knowledge resources," Strategic Management Journal, vol. 28, no. 10, pp. 1053-1064, 2007.

[26] G. Qian, L. Li, J. Li, and Z. Qian, "Regional diversification and firm performance," Journal of International Business Studies, vol. 39, no. 2, pp. 197-214, 2008.

[27] H. A. Siah, "International diversification: a "quick fix" for pressures in company performance?" University of Auckland Business Review, vol. 9, no. 1, pp. 17-23, 2007.

[28] S.-C. Chang and C.-F. Wang, "The effect of product diversification strategies on the relationship between international diversification and firm performance," Journal of World Business, vol. 42, no. 1, pp. 61-79, 2007.

[29] F. J. Contractor, V. Kumar, and S. K. Kundu, "Nature of the relationship between international expansion and performance: the case of emerging market firms," Journal of World Business, vol. 42, no. 4, pp. 401-417, 2007.

[30] R. La Porta, F. Lopez-de-Silanes, A. Shleifer, and R. Vishny, "Investor protection and corporate valuation," The Journal of Finance, vol. 57, no. 3, pp. 1147-1170, 2002.

[31] S. Claessens, S. Djankov, and L. H. P. Lang, "The separation of ownership and control in East Asian corporations," Journal of Financial Economics, vol. 58, no. 1-2, pp. 81-112, 2000.

[32] Y. Jung, "Multinationality and profitability," Journal of Business Research, vol. 23, no. 2, pp. 179-187, 1991. 
[33] A. Agrawal and C. R. Knoeber, "Firm performance and mechanisms to control agency problems between managers and shareholders," The Journal of Financial and Quantitative Analysis, vol. 31, no. 3, pp. 377-397, 1996.

[34] S.-Y. Wei, T. C. Chiao, and X.-W. Ye, "The clustering analysis of corporate ownership and control contestability based on shapley value," Cluster Computing, vol. 20, no. 3, pp. 2703-2723, 2017.

[35] M. Bradley, G. A. Jarrell, and E. H. Kim, "On the existence of an optimal capital structure: theory and evidence," The Journal of Finance, vol. 39, no. 3, pp. 857-878, 1984.

[36] R. Morck, A. Shleifer, and R. W. Vishny, "Management ownership and market valuation: an empirical analysis," Journal of Financial Economics, vol. 20, pp. 293-315, 1988.

[37] R. Mock and B. Yeung, "Why investors value multinationality," Journal of Business, vol. 64, no. 2, pp. 165-187, 1991.

[38] I. B. Kravis and R. E. Lipsey, "Sources of competitiveness of the United States and of its multinational firms," The Review of Economics and Statistics, vol. 74, no. 2, pp. 193-201, 1992.

[39] S. Z. A. Shah, A. W. Stark, and S. Akbar, "The value relevance of major media advertising expenditures: some U.K. evidence," The International Journal of Accounting, vol. 44, no. 2 , pp. 187-206, 2009.

[40] T. Ravichandran, Y. Liu, S. Han, and I. Hasan, "Diversification and firm performance: exploring the moderating effects of information technology spending," Journal of Management Information Systems, vol. 25, no. 4, pp. 205-240, 2009.

[41] S. C. Myers and S. Turnbull, "Determinants of corporate borrowing," Journal of Financial Economics, vol. 5, no. 2, pp. 147-175, 1977.

[42] R. Stulz, "Managerial discretion and optimal financing policies," Journal of Financial Economics, vol. 26, no. 1, pp. 3-27, 1990.

[43] Y. H. Yeh, T. S. Lee, and T. Woidtke, "Family control and corporate governance: evidence from Taiwan," International Review of Finance, vol. 2, no. 1-2, pp. 21-48, 2001.

[44] D. Yermack, "Higher market valuation of companies with a small board of directors," Journal of Financial Economics, vol. 40, no. 2, pp. 185-211, 1996.

[45] E. M. Fich and A. Shivdasani, "Are busy boards effective monitors?” Journal of Finance, vol. 61, no. 2, pp. 689-724, 2005.

[46] E. F. Fama, "Agency problems and the theory of the firm," Journal of Political Economy, vol. 88, no. 2, pp. 88-307, 1980. 